LOWER PROPENSITY TO PAY DIVIDENDS?

NEW EVIDENCE FROM EUROPE

\author{
Elisabete Vieira \\ Instituto Superior de Contabilidade e Administração \\ Universidade de Aveiro \\ Management Department \\ Rua Associação H. B. Voluntários \\ 3811-953 Aveiro \\ Portugal \\ Tel: 351234380110 \\ Fax: 351234380111 \\ elisabete.vieira@isca.ua.pt
}

\author{
Clara Raposo \\ ISCTE \\ Business School \\ Av. Prof. Aníbal de Bettencourt \\ 1600-189 Lisboa \\ Portugal
}

Tel: 351217958607

Fax: 351217958605

clara.raposo@iscte.pt 


\begin{abstract}
Recently, some empirical studies reported the phenomenon of the low propensity of firms to dividend payment, concluding that companies have become less likely to pay dividends. In addition, the major parts of these studies sustain the investors' expectations regarding dividend payments also decreased.

We analyse the propensity to pay dividends in three European markets: Portugal, France and the UK. Although they are all European markets, they are different from each other for several reasons. Firstly, the UK is one of the most important European capital markets, whereas the French and Portuguese markets are smaller, specially Portugal, that is a very small market compared to other Western European markets. Additionally, these two markets are less intensively researched. Secondly, we have differences in these countries associated with the ownership of equity. In Portugal and France ownership tends to be more concentrated than in the UK. Thirdly, Portugal and France are bank-based system, whereas the UK is a market-based system. Finally, the legal rules covering protection of corporate shareholders is different in the three countries. While the UK is a country of Anglo-Saxon influence, the other two countries are characterised by a continental influence.

We find evidence of the decline of firms paying dividends, except for the French market. Moreover, we find evidence suggesting that the Portuguese market does not have such a smoothing dividend policy like the US or the UK markets, but it has a more volatile dividend policy, such as the case of the German market.
\end{abstract}

Key Words: Cash Dividends, Dividend Payments

JEL Classification: G35, G32 


\section{LOWER PROPENSITY TO PAY DIVIDENDS? \\ NEW EVIDENCE FROM EUROPE}

\section{INTRODUCTION}

Recently some empirical studies reported the phenomenon of the low propensity of firms to dividend payment, sustaining investors' expectations regarding dividend payments also decreased. The first studies on this topic have analysed the US market.

Fama and French (2001) have studied the dividend payment decrease phenomenon in recent years on the American market. The number of firms that pay dividends has decreased significantly during the 1980's and 1990's, since in 1978, 66.5\% of firms listed on NYSE, AMEX and NASDAQ (excluding financial organizations and public utility) distributed dividends, while in 1999 this percentage was only 20.8\%. The authors state that there are three main factors for the dividend payment decision, which are profitability, growth and a firm's size. The firms that pay dividends tend to be the ones of larger size, higher profitability, but the ones having fewer growth opportunities. On the whole, and apart from these characteristics, firms tend to pay fewer dividends. The small propensity to pay dividends suggests that the perceived benefits of dividends have been decreasing through time, namely because of the fiscal disadvantage of it related to capital gains. If we consider share repurchases as an extra earnings payment to investors, the increase of share repurchases in the 1990s may imply an increase in the target payout ratio of dividends. However, it is necessary to be cautious as the global ratio disguises the evidence of a low propensity to dividend payments. As the evidence shows that share repurchases happen in firms that pay dividends, dividend decline is still unexplained ${ }^{1}$. About this phenomenon, Bratton (2005) refers that if dividends were the sole means of paying out cash, the payout ratio would have declined even more.

\footnotetext{
${ }^{1}$ Reynolds (2004) and Brav et al. (2005) examine the determinants of the choice between dividends and share repurchases, concluding that firms do not appear to randomly choose between the various payout choices. Reynolds (2004) observes the choice is the result of a deliberate and specific decision made by the firm in the interest of shareholders' wealth maximising, based on firms' characteristics and Brav et al.
} 
Banerjee, Gatchev and Spindt (2002) develop Fama and French's approach to evaluate the market liquidity increase effect on dividend payments between 1963 and 2001. The authors considered the hypothesis that market liquidity increase is negatively related to the proportion of firms that pay dividends, finding evidence that supports this hypothesis, since their results show that part of the lower motivation to pay dividends seems to be explained by the share transaction increase. When they estimated the probability that firms will pay dividends, taking into account the three factors defined by Fama and French (2001) - profitability, growth and firms size - they conclude that larger and more profitable firms pay higher dividends, while those that have more growth opportunities pay lower dividends, which is consistent with the former authors' results. Banerjee, Gatchev and Spindt conclude that the inferior propensity to dividend payment is not significantly influenced by fiscal reasons or by a firm's share repurchase policy.

Baker and Wurgler (2002) analyse possible causes for the change in the propensity to dividend payments between 1963 and 2000, emphasising the propensity decrease in the period after 1978, already documented by Fama and French (2001). They conclude that the best explanation for the disappearance of dividends is offered by the "catering theory of dividend ${ }^{2}$ ". Dividend payment by firms responds to investor demand for dividend proxies by the dividend premium, the difference between the market-to-book ratios of dividend payers and non-payers in a given year. Baker and Wurgler find no support for the asymmetric information theory or the clienteles' theory in influencing, at least in a significant way, the propensity to pay dividends.

DeAngelo, DeAngelo and Skinner (2004) find evidence of a substantial increase in the concentration of earnings as well as dividends between 1978 and 2000. In the last year, the 25 largest dividend paying firms account for over 50\% of the earnings and dividends paid. The authors conclude that the "repurchase puzzle" is not yet solved, since share repurchases have not displaced dividends as the preferred form of payout, despite their tax advantages. Like Baker and Wurgler, they argue that the aggregate evidence does not support either signalling or the clientele hypothesis.

(2005) conclude that maintaining the dividend level is on par with investment decisions, while repurchases are made out of the residual cash flow after investment spending.

${ }^{2}$ According to the authors, the catering theory supports the idea that firms tend to pay dividends when the share prices of the firms that distribute dividends are higher than those that do not pay it. 
Bulan, Subramanian and Tanlu (2004) study the changes in the characteristics of American listed firms around dividend initiations during the period 1963 to 1998 and suggest that the timing of dividend initiations is best explained by a synthesis of the maturity hypothesis [Grullon, Michaely and Swaminathan (2002)] with the catering theory [Baker and Wurgler (2002)]. Initiators are large firms, with slow growth and high profitability, as predicted by the maturity hypothesis ${ }^{3}$. However, they find no significant decline in risk around a dividend initiation, in contrast with Grullon, Michaely and Swaminathan's results for dividend increases. Their results are in line with the predictions of the catering theory, since dividend initiations are more likely when the premium is higher. In sum, initiations tend to occur when mature firms find an appropriate moment: when market sentiment favours dividends. Contrary to the signalling theory, Bulan, Subramanian and Tanlu find that dividend initiations do not signal any significant change in the growth rate or profitability of a firm. Furthermore, they conclude that repurchases and dividends play different roles, not being substitute methods of paying out cash.

Loderer and Roth (2005) examine whether the cash that firms distribute to their shareholders justifies the firm's share prices, studying a sample of firms traded on the NYSE, AMEX and NASDAQ in the 1926-2002 period. They found evidence that the importance of ordinary dividends as a means of cash distribution has fallen during the past three decades to a level between $10 \%$ and $49 \%$. Moreover, their results show that small firms pay cash dividends less frequently than the large firms and NASDAQ firms tend to pay ordinary dividends less often than AMEX and NYSE firms. Their results suggest a contemporaneous improvement in market liquidity. Furthermore, the evidence found is roughly consistent with information efficient markets.

Very recently, DeAngelo, DeAngelo and Stulz (2006) found evidence of no change in the companies' propensity to pay dividends from the mid-1970s to 2002 for the companies with negative retained earnings. However, the other firms have a propensity reduction that is approximately twice the overall reduction in Fama and French (2001).

Recent studies extend the analysis to other countries in addition to the US, such as Reddy and Rath (2005), Ferris, Sen and Yui (2004) and Osobov (2004).

\footnotetext{
${ }^{3}$ In the mature stage of their life cycle, these firms generate a lot of cash, but do not find many profitable investment opportunities.
} 
Reddy and Rath (2005) follow the Fama and French (2001) approach to analyse the impact of profitability, size and growth on the dividend payout of Indian firms over the 1990-2001 period. Their results document a decline in dividend-paying firms ${ }^{4}$. Further, they found that dividend-paying firms are more profitable and larger in size than nonpaying firms, which is in agreement with Fama and French's (2001) results. However, they found no significant relation between a firm's growth and dividend payments, which contradicts the findings of Fama and French.

Ferris, Sen and Yui (2004) test whether the recent disappearance of dividends is solely a US phenomenon or part of a more global trend, analysing eleven common law and fourteen civil law countries over the period from 1990 to $2001^{5}$. In general, their findings are consistent with patterns observed for US firms. They find that the propensity to pay dividends declines over there sample period and is most pronounced for firms incorporated in common law countries ${ }^{6}$. They find that the growing incidence of non-dividend paying firms is explained by the increase in the percentage of firms that have never paid dividends. What appears to be sensitive to the legal regime is the resistance to initiating dividends, more evident on common law nations. Furthermore, Ferris, Sen and Yui find that firms in common law countries tend to be more profitable, to have more abundant growth opportunities and to be bigger than their civil law counterparts.

Osobov (2004) analyses corporate dividend decisions of international firms, using the methodology of Fama and French (2001). The countries included in the analysis are the US, Canada, UK, Germany, France and Japan, for the period between 1981 and 2002. The results indicate a decline in the propensity of firms to pay dividends in all countries, although the magnitude of the decline and the percents of payers at the end of the study vary across countries ${ }^{7}$. The author evaluates whether firm size, profitability and growth opportunities affect dividend decisions. Larger and more profitable firms are more

\footnotetext{
${ }^{4}$ The percentage of Indian firms paying dividends has declined from 60.5\% in 1990 to 32.1\% in 2001.

5 The classification of the countries between common or civil law was based on La Porta et al. (1998). Examples of common law countries are Australia, Canada, Hong Kong, Thailand, UK and US, and civil law countries are Japan, France, Italy, Germany, Spain and Switzerland.

${ }^{6}$ At the beginning of their sample period, $81.4 \%$ of the sample firms pay dividends, but by 2001, this value declines to only 58.3\%. The US and Canadian firms exhibit the greatest decrease in the number of dividend payers.

${ }^{7}$ While in the US and Canada the proportion of dividend payers in 2002 is about 20\%, the corresponding proportion in the UK, Germany and France are in the range of 42.7 to $61.0 \%$ and in Japan is $83.8 \%$.
} 
likely to pay dividends in all countries, while the effect of growth opportunities depends on the country's legal origin. Consistent with the findings of La Porta et al. (2000) and Fama and French (2001), the relationship between growth opportunities and the likelihood of dividend payments in the US, Canada and UK is negative. However, in Germany, France, and Japan it is mixed. The author replicates the tests of Baker and Wurgler (2002) to evaluate the catering hypothesis and the results are consistent with catering theory in the common law countries but not in the civil law countries. Furthermore, Osobov finds results consistent with the agency theory. The high concentration of dividends among few large firms, which is consistent with some authors' evidence such as DeAngelo, DeAngelo and Skinner (2004), challenges the signalling theory. The results cast some doubts on equilibrium clientele theories and on signalling theories as candidate common explanations of the declining propensity to pay dividends. Moreover, Osobov finds no significant relationship between the propensity to pay dividends and share repurchases, which is consistent with the evidence of Fama and French (2001).

Although the recent evidence of a decline in the propensity of firms to pay dividends, they continue to be a relevant topic in the finance literature.

The remainder of this paper is organised as follows. Section 2 presents the sample selection. Section 3 presents and discusses the empirical results and section 4 provides the conclusion.

\section{SAMPLE SELECTION}

The sample is drawn from dividend announcements of firms listed on the Euronext Lisbon (EL), Euronext Paris (EP) and LSE. For the French and UK markets, we consider the dividend announcements between $1994^{8}$ and 2002. Announcement dates are available on Bloomberg database and all other needed information is available on Datastream database. For the Portuguese market we consider the dividend

\footnotetext{
${ }^{8}$ The first year (1994) is conditioned by the availability of announcement dates on Bloomberg database.
} 
announcements between 1988 and 2002 ${ }^{9}$. Because Bloomberg and Datastream lack information on the Portuguese market, we obtain data from Dhatis, an EL database and we also needed to collect some financial statements directly from the companies.

We consider all the non-financial listed firms whose data are available on Datastream or Dhatis databases. We exclude financial firms to be consistent with other studies done in this subject, like the ones of Fama and French (2001) and Banerjee, Gatchev and Spindt (2002).

\section{EMPIRICAL RESULTS}

We start this section by presenting the trends in the dividend payment pattern of the non-financial listed firms on the three markets. Following, we compare these results with several studies done in the US market, like the ones of Fama and French (2001), Baker and Wurgler (2002) and Reynolds (2004), as well as abroad the US market, such as the recent studies of Ferris, Sen and Yui (2004), applied to eleven common law and fourteen civil law countries, and Osobov (2004), applied to US, Canada, UK, Germany, France and Japan.

Table 1 shows the total number of non-financial firms listed on EL, EP and LSE each year during the period considered in each country, and the number of firms that, for each year, pay cash dividends (payers) and do not pay cash dividends (non-payers), according to the information available on Datastream database.

The Portuguese market is smaller than other Western European markets, namely the UK and French markets, as we can see by the smaller number of non-financial listed firms. We want to begin by emphasising the significant decline in the total number of nonfinancial firms listed on EL during the sample period. It has fallen from 140 in 1988, to 43 , in 2002, representing a decline of about $69.3 \%$. The decline along the period is due, in part, to firms disappearing through merger and acquisitions or bankruptcy. The Portuguese market specificities of instability, illiquidity and thin trading influence this

\footnotetext{
${ }^{9}$ For the Portuguese sample we consider a longer period than for the two other samples, in order to maximise the number of observations, since this is a small market, with a small number of dividend events (as we will see later).
} 
general behaviour. Although this decline is continuous, it declines sharply from 1991 to 1992. During this specific period the market suffered a structural and functional reform, with the publication of the Securities Market Code and the establishment of the Portuguese Securities Market Commission (CMVM). The new rules of supervision and market regulation lead to a significant number of delisted firms.

The number of non-financial firms that paid dividends has fallen continuously from 93 firms in 1988 to only 18 in 2002. However, the percentage of companies paying dividends has declined only from $66.43 \%$ in 1988 to $41.86 \%$ in 2002 . This is explained by the fact that the total number of firms listed on EL also declined significantly, as we said before and which can be seen also in Figure 1 . So, both the decline of the numerator (the number of dividend payers) and the denominator (the number of sample firms) contribute to the softer decline of percents. In the last two years the percentage of firms that do not pay dividends became higher than that of dividend payers, which coincides with a period of market recession ${ }^{10}$.

In France, the total number of non-financial firms listed on EP has decreased continuously during the sample period. It has decreased from 414 firms in 1992, to 224, in 2002. However, the number of non-financial firms that paid dividends has grown continuously from 1992 (101 firms) to 2001 (150 firms), representing an increase of 48.5\%. However, from 2001 to 2002, the number of dividend payers has fallen to 146, but we cannot say firms become less likely to pay dividends, as the total number of nonfinancial firms has also declined. The percentage of dividend payers increased from $24.40 \%$ to $65.18 \%$ in the $1992-2002$ period, which is significant. The difference between absolute and relative values is due to the relevant decrease of the total number of non-financial firms listed on EP. Although Osobov (2004) found a low percentage decline in dividend payers in the French market, he points out the fact that the percentage of payers is significantly higher than the percentage of dividend nonpayers $^{11}$. The increase of the numerator (the number of dividend payers) and the decrease of the denominator (the number of sample firms) contribute to the higher growth of the percentage. Surprisingly, in 1999, the number of dividend payers became

\footnotetext{
${ }^{10}$ The decline in the percent of firms paying dividends raises the issues of what are the characteristics of dividend payers and if firms with these characteristics become less likely to pay dividends, but we will not address these questions since this is beyond the scope of this study.

${ }^{11}$ Although he finds a percentage of dividend payers of $62.9 \%$ for 2001 and $61.0 \%$ for 2002 , we find the percentages of, respectively, $61.73 \%$ and $65.18 \%$, which are not very different.
} 
higher than that of dividend non-payers, and this relation is maintained until 2002, as we can see easily in Figure 1.

The UK market is the most significant capital market in our study. It shows an increase in the total number of non-financial firms listed on LSE during the period from 1994 to 2000, in contrast to what happens in Portugal and France. It has increased from 753 firms in 1994, to 984, in 2000. However, this number declined during the two subsequent years, and, in 2002, this number has declined to 940. In fact, the year 2001 was characterised by a slowing down in the world economic growth, which can explain this evolution. The number of non-financial firms that paid dividends has increased continuously from 1994 to 2000, but it has decreased in 2001 and 2002. In spite of the decrease in the number of dividend payers, in percentage it does not happen, because the number of total non-financial firms has a higher decline. The percentage of dividend payers is slightly higher than the percentage of non-dividend payers, as we can also see in Figure 1. The same evidence was found by Osobov (2004) and Ferris, Sen and Yui $(2004)^{12}$.

Overall, the evidence found in several recent studies of the decline of firms paying dividends in different markets, such as the US market [Fama and French (2001) and Baker and Wurgler (2002)], several common and civil law countries, including European Markets [Ferris, Sen and Yui (2004) and Osobov (2004)] and the Indian market [ Reddy and Rath (2005)], being this last one a small market, are consistent with our findings for Portugal, and, partially for the UK, but in contrast with France results. Moreover, the results suggest that European markets have a higher percentage of dividend payers firms, independently of the evolution. In the year of 1999, the percentage of firms paying dividends in the US market was 20.8\% [Fama and French (2001)], in India was 32.1\%, including financial firms [ Reddy and Rath (2005)], and we find a percentage of $67.86 \%$ for Portugal, $53.14 \%$ for France and $53.17 \%$ for the UK market.

\footnotetext{
${ }^{12}$ Our numbers for the French and the UK markets differ from the ones of Osobov (2004) and Ferris, Sen and Yui (2004). However, the first author collected his data from Worldscope database and the latter authors obtain the data on the July 2002 edition of the Company Analysis database (a Thompson Financial product). We obtain the number of firms listed in each year directly from EP, for the French market, and from LSE, for the UK market and the information of dividend payers in Datastream database. Osobov and our study consider only the non-financial firms. In 2001, the last common year for the three studies, the percentage of dividend payers for the French market was 59.3\%, $62.9 \%$ and $61.7 \%$ and for the UK market was 53.0\%, 60.4\% and 53.1\%, respectively in the Ferris, Sen and Yui, Osobov and in our study.
} 
Table 2 contains some summary statistics concerning the DPS. In Portugal, the average DPS has ranged from 1988 to 2002 between 0.15 (2002) and 0.64 Euros (2001) and the maximum value has ranged from 0.70 (2002) to 10.47 (2001). The last two years present very different values for the average DPS, being 2001 the year with the higher standard deviation (2.16). However, the year of 2001 is highly influenced by a unique dividend of 10.47 euros. If we ignore this dividend, we will have an average of 0.19 (one of the lowest), a maximum value of 1.00 and a standard deviation of 0.24 , which is more consistent with the recession period of 2001-2002, as it can be seen in Figure 3.2, as well as by the lowest values for the minimum DPS both in 2001 and 2002, of 0.01 euros.

The fact that the percentage of firms paying dividends has been relatively constant whereas the average dividend paid has decreased, namely in the 1995-2002 period, implies that companies which have been paying dividends have paid lower amounts, except a small number of bigger size firms.

In France, the DPS values are highly influenced by a unique firm with extreme dividends (in average, above 90 Euros), as we can see in Figure 2. Thus, we decide to ignore this firm for DPS analysis. According to Table 2, the average DPS (in Euros) has ranged from 1992 to 2002 between 1.34 (1996) and 1.91 (1993). The average DPS has been stable in the last five years, with an increase tendency, which is consistent with firms smoothing their dividends. The minimum DPS is also stable. The higher movements are observed in the maximum dividends that ranged from 1992 to 2002 between 10.98 (1996) and 52.85 (1993 and 1994).

In the UK market, the average DPS values (in $£$ ) have increased continuously from 6.33, in 1994 to 9.83, in 2002. The tendency of a continuous increase in the average DPS could be interpreted as an indication of firms smoothing their dividends. The high values for the standard deviation can be explained by the significant different between the minimum and maximum values of DPS.

The UK firms pay higher dividends than the Portuguese and French markets, probably because it is one of the most important European capital markets. 
Industry trends from the length period can be seen in Table 3. Panel A shows the average DPS and Panel B the percentage of dividend payers, both by industry breakdown.

Portugal shows evidence of an unstable market, as we can see in Panel A, with some activity sectors that simply omitted the dividend payments along the period. There are two main reasons for that to happen: some of the firms have been delisted during the analysed period and others have been closed, namely because they went bankrupt, such as in the agriculture and textile sectors. From the sectors with regular dividend payments in 1988-2002, firms in the telecommunication, machines and electrical equipment and metallurgy sectors have paid more dividends whereas construction and restaurants, hotels and leisure have paid the lowest levels.

In Panel B we can see some instability in the percentage of dividend payers along the period 1988-2002. It can be due to two different kinds of reasons: first, it can be caused by a relative frequency that some firms are listed and delisted in the EL from one year to the other and the fact that some sectors have a small number of firms, and, in some sectors, only one firm such as the case of electricity and tobacco sectors. Finally, it must be a signal that the Portuguese market does not have such a smoothing dividend policy like the US or the UK markets, but it has a more volatile dividend policy, such as the case of the German market [Goergen, Renneboog and Silva (2005)]. Chemicals and IT systems along with metallurgy sectors have the highest share of dividend payers along the period. However, among them, only the metallurgy sector pays the higher DPS, as we have seen in Panel A. In contrast, transport activities and wholesale trade have the lowest percentage of dividend payers. Chemicals, construction, mineral non metallic industries and other services sectors are the ones that have a greater stability in the dividend payers' percentage along the period, which, in global terms, coincides with the sectors that have more stability in the firms being listed between 1988 and 2002.

For the French market, and as we have done for the DPS analysis, we exclude a firm with extreme dividend payments; otherwise the results for its sector would be inconsistent. As we can see in Panel A, all the activity sectors paid dividends during the period 1992-2002, except for the tobacco sector, which have listed firms since 1995 (Panel B) and begun paying dividends in 2000 (Panel A). From the sectors with regular dividend payments in 1992-2002 period, firms in the food and beverages and real estate 
sectors have paid more dividends whereas IT systems and machines and electrical equipment have paid the lowest levels.

In Panel B we can see that, globally, the percentage of dividend payers has grown continuously along the period 1992-2002. Automobile and construction sectors have the highest share of dividend payers along the period. In contrast, diversified industries and services have the lowest percentage of dividend payers. The paper sector presents a significant increase in the percentage of dividend payers, but this is mainly because of the significant decrease of the number of listed firms in this sector of activity.

In the UK market, all the activity sectors paid dividends during the period 1994-2002, except for the metallurgy sector, which has begun paying dividends in 1999. From the sectors with regular dividend payments in 1994-2002 period, firms in the agriculture and tobacco sectors have paid higher average DPS whereas telecoms and IT systems have paid the lowest levels.

In Panel B we can see that the percentage of dividend payers has grown in some activity sectors, but is has declined in others. Construction, electricity, mineral non metallic products and paper sectors have the highest increase in their percentage of dividend payers. In contrast, agriculture, telecoms, IT and diversified services have the more important decrease in the percentage of dividend payers.

In sum, these results show some evidence of industry and countries effects in dividend payments.

\section{CONCLUSIONS}

The evidence found in several studies of the decline of firms paying dividends in different markets, such as in the studies of Fama and French (2001), Baker and Wurgler (2002), Ferris, Sen and Yui (2004) and Osobov (2004), are consistent with our findings for Portugal, and, partially for the UK, but in contrast with France results. In fact, we find that firms become less likely to pay dividends in the Portuguese and, for the recent years, in the UK market, but not in the French market, where The percentage of dividend payers increased from $24.40 \%$ to $65.18 \%$ in the $1992-2002$ period. 
Moreover, the results suggest that European markets have a higher percentage of dividend payers than other markets, independently of the evolution. In the year of 1999, the percentage of firms paying dividends in the US market was 20.8\% [Fama and French (2001)], in India was 32.1\%, including financial firms [ Reddy and Rath (2005)], and we find a percentage of $67.86 \%$ for Portugal, 53.14\% for France and 53.17\% for the UK market. The UK firms pay higher dividends than the Portuguese and French markets, probably because it is one of the most important European capital markets.

Forwards, we find evidence suggesting that the Portuguese market does not have such a smoothing dividend policy like the US or the UK markets, but it has a more volatile dividend policy, such as the case of the German market [Goergen, Renneboog and Silva (2005)].

Finally, we find some evidence of industry and countries effects in dividend payments.

In terms of suggestions for future research in this field, we wish to consider particular aspects that can improve the empirical results, as well as go further in this domain. Firstly, we wish to enlarge our sample period, considering the same sample period for the three markets. Secondly, we would like to split the sample in different sub periods, in order to detect some different phenomenon in the market that can influence the results. Finally, we would like to analyse which are the firms' characteristics that can distinguish the dividend payers from the non-payers, namely the profitability, assets growth, firm's size, market to book ratio and the financial distress. The firms that pay dividends tend to be the ones of larger size, higher profitability, but the ones having fewer growth opportunities. 


\section{REFERENCES}

Baker, Malcolm P. and Wurgler, Keffreu, 2002, "Why are Dividends Disappearing? An Empirical Analysis”, Harvard NOM Working Paper nº 03-12.

Banerjee, Suman, Gatchev, Vladimir A. and Spindt, Paul A., 2002, "To Pay or not to Pay? The Dividend Dilemma of the Liquid Firm”, Working Paper, Freeman School of Business, Tulane University.

Bratton, William W., 2005, “The New Dividend Puzzle”, Georgetown Law Journal 93 (3).

Brav, Alon, Graham, John R., Harvey, Campbell R. and Michaely, Roni, 2005, “Payout Policy in the 21st Century”, Journal of Financial Economics 77 (3), 483-528.

Bulan, Laarni T., Subramanian, Narayanan and Tanlu, Loyd D., 2004, "On the Timing of Dividend Initiations”, Working Paper, SSRN Working Papers.

DeAngelo, Harry, DeAngelo, Linda and Skinner, Douglas J., 2004, “Are Dividends Disappearing? Dividend Concentration and the Consolidation of Earnings”, The Journal of Financial Economics 72 (3), 445-456.

DeAngelo, Harry, DeAngelo, Linda and Stulz, René M., 2006, "Dividend Policy and the Earned/Contributed Capital Mix: A Test of the Life-cycle Theory”, The Journal of Financial Economics 81 (2), 222-254.

Fama, Eugene F. and French, Kenneth R., 2001, "Disappearing Dividends: Changing Firm Characteristics or Lower Propensity to Pay?”, Journal of Financial Economics 60 (1), 3-43.

Ferris, Stephen P., Sen, Nilanjan and Yui, Ho Pei, 2004, "International Trends in Dividend Payment: the Influence of Legal Regime”, Working Paper presented at 2004 FMA Annual Meeting.

Goergen, Marc, Renneboog, Luc and Silva, Luis Correia, 2005, "When do German Firms Change their Dividends?”, Journal of Corporate Finance 11 (2), 375-399.

Grullon, Gustavo, Michaely, Roni and Swaminathan, Bhaskaran, 2002, “Are Dividends Changes a Sign of Firm Maturity?”, The Journal of Business 75 (3), 387-424. 
La Porta, Rafael, Lopes-de-Silanes, Florencio, Shleifer, Andrei and Vishny, Robert W., 1998, “Law and Finance”, The Journal of Political Economy 106 (6), 1113-1155.

La Porta, Rafael, Lopes-de-Silanes, Florencio, Shleifer, Andrei and Vishny, Robert W., 2000, “Agency Problems and Dividend Policies around the World”, The Journal of Finance 55 (1), 1-33.

Loderer, Claudio and Roth, Lukas, 2005, "Do Cash Payouts Justify Share Prices? Evidence from the NYSE, Amex and NASDAQ”, Working Paper presented at 2005 Annual Meeting of EFMA.

Osobov, Igor, 2004, "Why Are Dividends Disappearing? An International Comparison”, Working Paper presented at 2004 FMA Annual Meeting.

Reddy, Y. Subba and Rath, Subhrendu, 2005, "Disappearing Dividends in Emerging Markets?”, Emerging Markets, Finance \& Trade, 41 (6), 58- 82.

Reynolds, Noel R., 2004, “The Firm’s Payout Policy Choice and Stockholder Wealth Maximization”, Working Paper presented at 2004 FMA Annual Meeting. 


\section{Table 1 - Trends in dividend payments}

This table reports the number of non-financial firms listed on EL in the period 1988-2002, on EP in the period 1992-2002 and on LSE in the period 1994-2002, as well as the number of firms in two different dividend groups: dividend payers (firms that pay dividends in year $t$ ) and dividend non-payers. The firm must be listed on December of year $t$ to be in the sample for that year.

\begin{tabular}{|c|c|c|c|c|c|}
\hline \multicolumn{6}{|c|}{ Trends in Dividend Payments } \\
\hline \multirow{2}{*}{ Year } & \multicolumn{2}{|c|}{ Payers } & \multicolumn{2}{|c|}{ Non-Payers } & \multirow{2}{*}{$\begin{array}{l}\text { Total } \mathrm{N}^{\circ} \\
\text { of Firms }\end{array}$} \\
\hline & $\mathrm{N}^{\mathrm{o}}$ & $\%$ & $\mathrm{~N}^{\mathrm{o}}$ & $\%$ & \\
\hline \multicolumn{6}{|c|}{ Portugal: Period 1988-2002 } \\
\hline 1988 & 93 & 66.43 & 47 & 33.57 & 140 \\
\hline 1989 & 93 & 72.09 & 36 & 27.91 & 129 \\
\hline 1990 & 82 & 65.60 & 43 & 34.40 & 125 \\
\hline 1991 & 75 & 60.48 & 49 & 39.52 & 124 \\
\hline 1992 & 51 & 69.86 & 22 & 30.14 & 73 \\
\hline 1993 & 37 & 60.66 & 24 & 39.34 & 61 \\
\hline 1994 & 29 & 51.79 & 27 & 48.21 & 56 \\
\hline 1995 & 26 & 50.98 & 25 & 49.02 & 51 \\
\hline 1996 & 30 & 58.82 & 21 & 41.18 & 51 \\
\hline 1997 & 31 & 55.36 & 25 & 44.64 & 56 \\
\hline 1998 & 37 & 61.67 & 23 & 38.33 & 60 \\
\hline 1999 & 38 & 67.86 & 18 & 32.14 & 56 \\
\hline 2000 & 31 & 58.49 & 22 & 41.51 & 53 \\
\hline 2001 & 23 & 46.94 & 26 & 53.06 & 49 \\
\hline 2002 & 18 & 41.86 & 25 & 58.14 & 43 \\
\hline \multicolumn{6}{|c|}{ France: Period 1992-2002 } \\
\hline 1992 & 101 & 24.40 & 313 & 75.60 & 414 \\
\hline 1993 & 111 & 29.13 & 270 & 70.87 & 381 \\
\hline 1994 & 109 & 29.54 & 260 & 70.46 & 369 \\
\hline 1995 & 120 & 33.15 & 242 & 66.85 & 362 \\
\hline 1996 & 120 & 36.59 & 208 & 63.41 & 328 \\
\hline 1997 & 124 & 40.79 & 180 & 59.21 & 304 \\
\hline 1998 & 129 & 45.74 & 153 & 54.26 & 282 \\
\hline 1999 & 144 & 53.14 & 127 & 46.86 & 271 \\
\hline 2000 & 141 & 53.61 & 122 & 46.39 & 263 \\
\hline 2001 & 150 & 61.73 & 93 & 38.27 & 243 \\
\hline 2002 & 146 & 65.18 & 78 & 34.82 & 224 \\
\hline \multicolumn{6}{|c|}{ UK: Period 1994-2002 } \\
\hline 1994 & 358 & 47.54 & 395 & 52.46 & 753 \\
\hline 1995 & 398 & 47.95 & 432 & 52.05 & 830 \\
\hline 1996 & 429 & 48.04 & 464 & 51.96 & 893 \\
\hline 1997 & 456 & 48.72 & 480 & 51.28 & 936 \\
\hline 1998 & 487 & 49.80 & 491 & 50.20 & 978 \\
\hline 1999 & 511 & 53.17 & 450 & 46.83 & 961 \\
\hline 2000 & 512 & 52.03 & 472 & 47.97 & 984 \\
\hline 2001 & 507 & 53.09 & 448 & 46.91 & 955 \\
\hline 2002 & 507 & 53.94 & 433 & 46.06 & 940 \\
\hline
\end{tabular}


Figure 1 - Dividend payers and non-payers

This figure shows the total number of non-financial firms listed on EL, EP and LSE, as well as the number of payers (firms that pay dividends in year $t$ ) and dividend non-payers. The firm must be listed on December of year $t$ to be in the sample for that year.

Portugal: 1988-2002

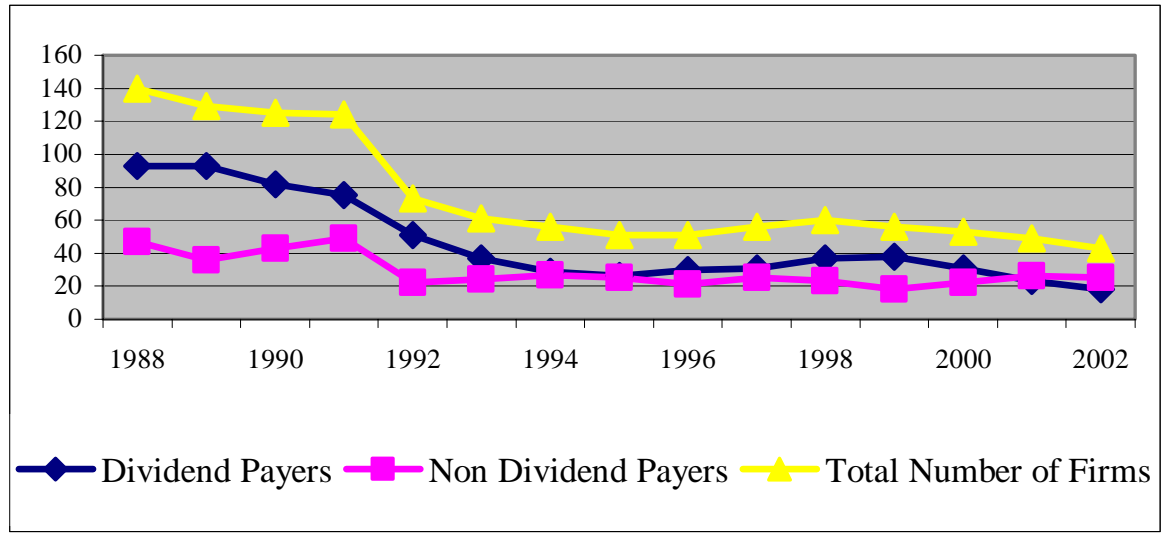

France: 1992-2002

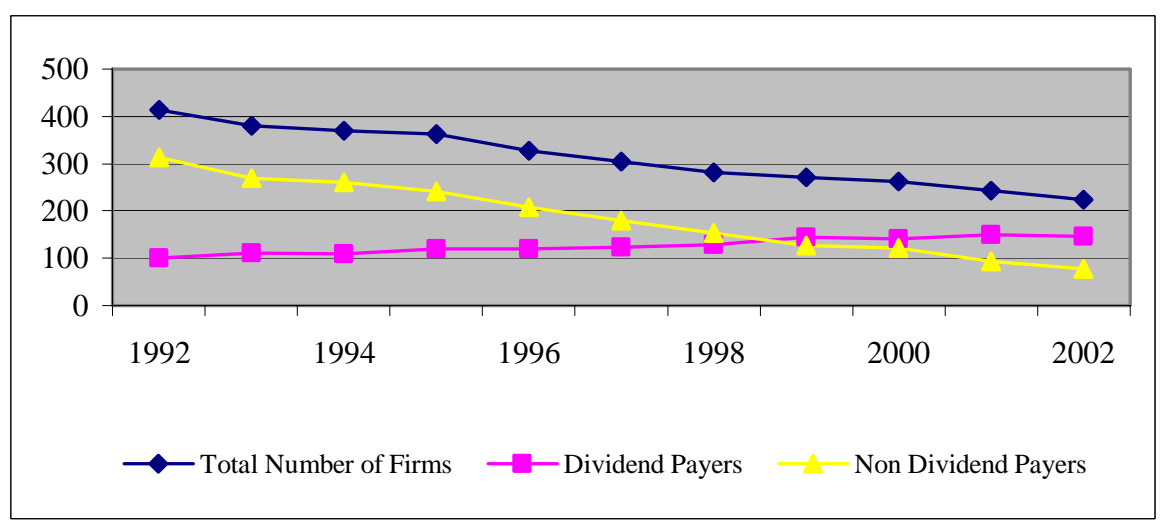

UK: 1994-2002

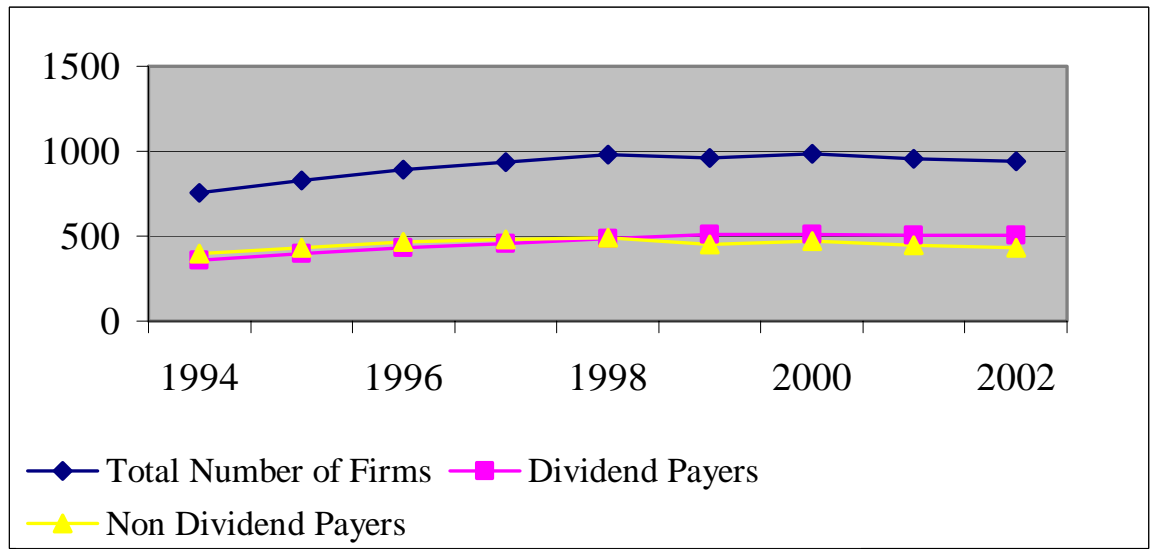


Table $\mathbf{2}$ - Summary statistics of dividend per share

This table reports the dividend per share (DPS) of non-financial firms listed on EL in the period 19882002, on EP in the period 1992-2002 and on LSE in the period 1994-2002. The firm must be listed on December of year $t$ to be in the sample for that year.

\begin{tabular}{|c|c|c|c|c|c|}
\hline \multicolumn{6}{|c|}{ Summary statistics of DPS } \\
\hline Year & $\begin{array}{c}\text { Dividend } \\
\text { Payers }\end{array}$ & $\begin{array}{l}\text { Minimum } \\
\text { DPS }\end{array}$ & $\begin{array}{c}\text { Maximum } \\
\text { DPS }\end{array}$ & $\begin{array}{c}\text { Average } \\
\text { DPS }\end{array}$ & $\begin{array}{c}\text { Std. } \\
\text { Deviation }\end{array}$ \\
\hline \multicolumn{6}{|c|}{ Portugal: Period 1988-2002, $€$} \\
\hline 1988 & 93 & 0.02 & 1.55 & 0.51 & 0.34 \\
\hline 1989 & 93 & 0.05 & 2.49 & 0.48 & 0.39 \\
\hline 1990 & 82 & 0.02 & 2.37 & 0.51 & 0.42 \\
\hline 1991 & 75 & 0.05 & 2.84 & 0.48 & 0.38 \\
\hline 1992 & 51 & 0.03 & 1.50 & 0.41 & 0.30 \\
\hline 1993 & 37 & 0.10 & 1.95 & 0.46 & 0.37 \\
\hline 1994 & 29 & 0.10 & 1.50 & 0.45 & 0.37 \\
\hline 1995 & 26 & 0.10 & 0.75 & 0.34 & 0.17 \\
\hline 1996 & 30 & 0.12 & 0.87 & 0.36 & 0.18 \\
\hline 1997 & 31 & 0.09 & 1.80 & 0.42 & 0.32 \\
\hline 1998 & 37 & 0.10 & 1.50 & 0.41 & 0.29 \\
\hline 1999 & 38 & 0.09 & 2.24 & 0.46 & 0.41 \\
\hline 2000 & 31 & 0.09 & 1.00 & 0.39 & 0.27 \\
\hline 2001 & 23 & 0.01 & 10.47 & 0.64 & 2.16 \\
\hline 2002 & 18 & 0.01 & 0.70 & 0.15 & 0.17 \\
\hline \multicolumn{6}{|c|}{ France: Period 1992-2002, $€$} \\
\hline 1992 & 101 & 0.02 & 14.48 & 1.57 & 2.33 \\
\hline 1993 & 111 & 0.02 & 52.85 & 1.91 & 5.16 \\
\hline 1994 & 109 & 0.02 & 52.85 & 1.90 & 5.19 \\
\hline 1995 & 120 & 0.02 & 14.48 & 1.43 & 2.13 \\
\hline 1996 & 120 & 0.01 & 10.98 & 1.34 & 1.61 \\
\hline 1997 & 124 & 0.02 & 25.15 & 1.57 & 2.64 \\
\hline 1998 & 129 & 0.01 & 16.77 & 1.51 & 2.04 \\
\hline 1999 & 144 & 0.01 & 19.82 & 1.61 & 2.28 \\
\hline 2000 & 141 & 0.02 & 19.82 & 1.63 & 2.23 \\
\hline 2001 & 150 & 0.01 & 19.82 & 1.74 & 2.29 \\
\hline 2002 & 146 & 0.04 & 25.00 & 1.83 & 2.58 \\
\hline \multicolumn{6}{|c|}{ UK: Period 1994-2002, £ } \\
\hline 1994 & 358 & 0.01 & 37.00 & 6.33 & 5.55 \\
\hline 1995 & 398 & 0.10 & 38.00 & 6.46 & 5.87 \\
\hline 1996 & 429 & 0.10 & 38.00 & 6.95 & 6.21 \\
\hline 1997 & 456 & 0.01 & 76.11 & 7.49 & 7.30 \\
\hline 1998 & 487 & 0.10 & 65.92 & 7.87 & 7.52 \\
\hline 1999 & 511 & 0.06 & 70.97 & 8.30 & 8.11 \\
\hline 2000 & 512 & 0.10 & 70.97 & 8.95 & 8.95 \\
\hline 2001 & 507 & 0.05 & 78.00 & 9.31 & 9.35 \\
\hline 2002 & 507 & 0.13 & 88.75 & 9.83 & 10.34 \\
\hline
\end{tabular}


Figure 2 - Average dividend per share

This figure shows the average DPS of non-financial firms listed on EL, EP and LSE. The firm must be listed on December of year $t$ to be in the sample for that year. We have also considered the average DPS excluding the sample extreme DPS value.

Portugal: 1988-2002, $€$

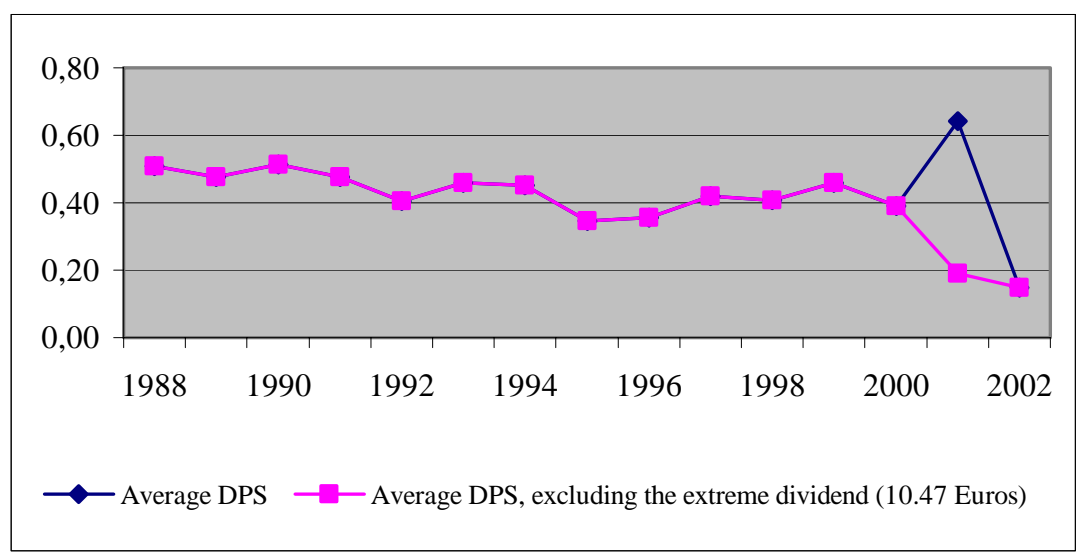

France: 1992-2002, $€$

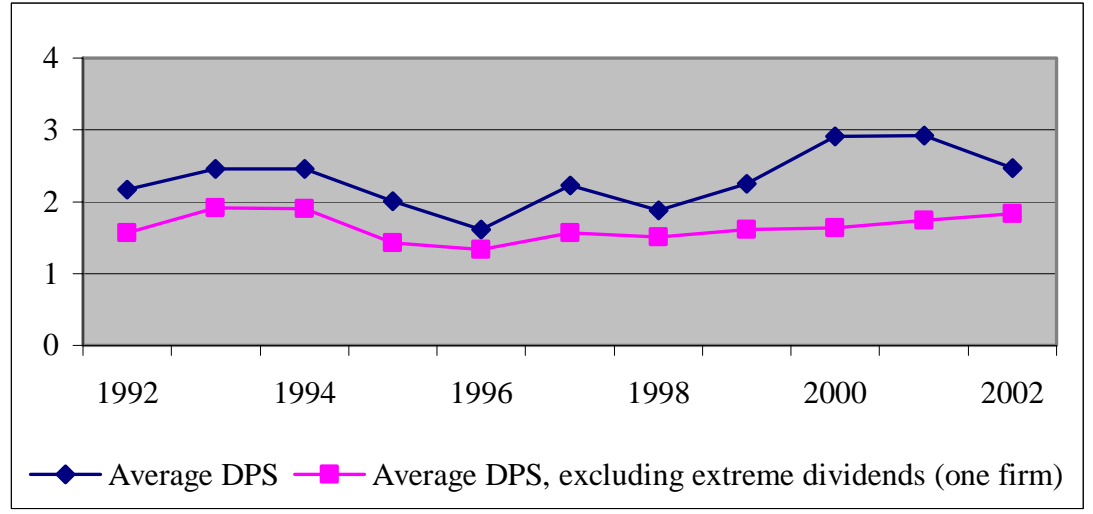

UK: 1994-2002, £

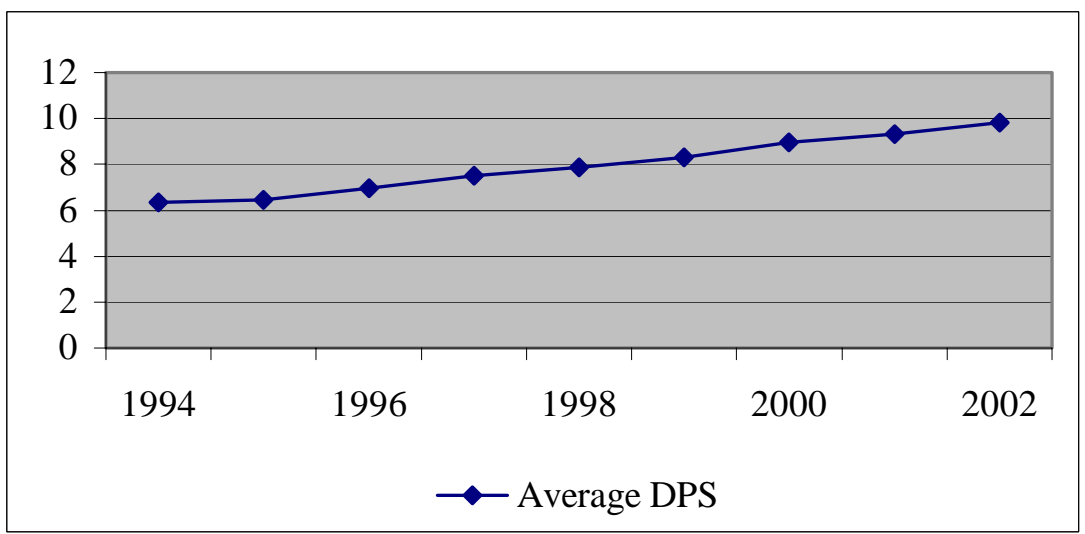




\section{Table 3 - Dividend statistics by industry breakdown}

This table reports the average DPS (Panel A) and the percentage of dividend payers (Panel B) by nonfinancial firms listed on EL, EP and LSE, classified by industry type. The firm must be listed on December of year $t$ to be in the sample for that year.

\begin{tabular}{|c|c|c|c|c|c|c|c|c|c|c|c|c|c|c|c|}
\hline \multicolumn{16}{|c|}{ Portugal } \\
\hline \multicolumn{16}{|c|}{ Panel A: Average DPS During 1988-2002 - Industry Breakdown, $€$} \\
\hline Industry & 1988 & 1989 & 1990 & 1991 & 1992 & 1993 & 1994 & 1995 & 1996 & 1997 & 1998 & 1999 & 2000 & 2001 & 2002 \\
\hline Agriculture & 0.33 & 0.34 & 0.42 & 0.35 & 0.15 & - & - & - & - & - & - & - & - & - & - \\
\hline Automobile & 0.70 & 0.70 & 0.50 & 0.30 & 0.40 & 0.40 & 0.36 & 0.40 & 0.15 & 0.37 & 0.40 & 0.65 & 1.00 & 0.20 & 0.08 \\
\hline Chemicals & 0.55 & 0.42 & 0.38 & 0.48 & 0.34 & 0.43 & 0.23 & 0.37 & 0.44 & 0.40 & 0.48 & 0.37 & 0.23 & 0.10 & 0.11 \\
\hline Communications & 1.14 & 2.19 & 2.37 & 2.84 & 1.21 & 0.59 & 0.65 & - & 0.45 & 0.69 & 1.19 & 1.63 & 0.20 & - & 0.10 \\
\hline Construction & 0.42 & 0.26 & 0.30 & 0.23 & 0.22 & 0.21 & 0.19 & 0.27 & 0.21 & 0.22 & 0.26 & 0.21 & 0.23 & 0.03 & 0.06 \\
\hline Diversified Retailers & 0.29 & 0.24 & 0.27 & 0.37 & 0.19 & - & - & - & - & - & - & - & - & - & - \\
\hline Electricity & - & - & - & - & - & - & - & - & - & - & 0.65 & 0.70 & 0.70 & 0.14 & 0.11 \\
\hline Food and Beverages & 0.45 & 0.45 & 0.52 & 0.53 & 0.39 & 0.57 & 0.46 & 0.27 & 0.35 & 0.31 & 0.41 & 0.57 & 0.32 & - & - \\
\hline Informatic Systems & 1.02 & 1.02 & 0.91 & 0.59 & 0.50 & 0.50 & 0.15 & 0.25 & 0.25 & 0.25 & 0.25 & 0.25 & 0.25 & 0.25 & - \\
\hline Machines and Electrical Equipment & 0.53 & 0.61 & 1.05 & 0.73 & 0.96 & 1.06 & 1.15 & 0.40 & 0.42 & 0.36 & 0.30 & 0.35 & - & - & - \\
\hline Metallurgy & 0.61 & 0.52 & 0.47 & 0.29 & 0.50 & 0.45 & 0.45 & 0.28 & 0.24 & 1.15 & 0.47 & 0.75 & 1.00 & 1.00 & - \\
\hline Mineral non Metallic Industries & 0.56 & 0.43 & 0.43 & 0.47 & 0.36 & 0.37 & 0.28 & 0.33 & 0.38 & 0.54 & 0.45 & 0.42 & 0.38 & 0.68 & 0.70 \\
\hline Other Services Rendered to Firms & 0.55 & 0.57 & 0.53 & 0.50 & 0.49 & 0.47 & 0.73 & 0.45 & 0.48 & 0.49 & 0.40 & 0.40 & 0.36 & 0.07 & 0.07 \\
\hline Paper & 0.29 & 0.47 & 0.35 & 0.52 & 0.25 & - & - & 0.25 & 0.26 & 0.17 & 0.19 & 0.17 & 0.42 & 5.25 & 0.05 \\
\hline Real Estate & 0.87 & 1.00 & 0.40 & 0.37 & 0.25 & 0.25 & 0.25 & 0.25 & 0.25 & 0.15 & 0.15 & 0.15 & 0.15 & 0.15 & - \\
\hline Restaurants. Hotels and Leisure & 0.42 & 0.36 & 0.30 & 0.26 & 0.24 & 0.30 & 0.25 & 0.25 & 0.15 & 0.19 & 0.18 & 0.26 & 0.53 & 0.19 & 0.25 \\
\hline Textiles & 0.59 & 0.41 & 0.41 & 0.52 & 0.24 & - & - & - & - & - & - & - & - & - & - \\
\hline Tobacco & 1.00 & - & 1.00 & - & 1.00 & 1.10 & 0.50 & 0.40 & 0.50 & - & - & - & - & - & - \\
\hline Transport Activities & 0.31 & 0.51 & 0.86 & 0.62 & 0.42 & 0.35 & - & - & - & - & 0.52 & 0.76 & 0.26 & 0.32 & 0.24 \\
\hline Wholesale Trade & 0.39 & 0.33 & 0.30 & 0.46 & 0.25 & - & - & - & - & - & - & 0.40 & 0.40 & - & - \\
\hline \multicolumn{16}{|c|}{ Panel B: Percentage of Dividend Payers by Industry Breakdown } \\
\hline Industry & 1988 & 1989 & 1990 & 1991 & 1992 & 1993 & 1994 & 1995 & 1996 & 1997 & 1998 & 1999 & 2000 & 2001 & 2002 \\
\hline Agriculture & 80.0 & 80.0 & 60.0 & 50.0 & 100.0 & - & - & - & - & - & - & - & - & - & - \\
\hline Automobile & 33.3 & 33.3 & 33.3 & 50.0 & 50.0 & 100.0 & 100.0 & 100.0 & 100.0 & 100.0 & 50.0 & 50.0 & 50.0 & 50.0 & 100.0 \\
\hline Chemicals & 66.7 & 100.0 & 85.7 & 62.5 & 83.3 & 100.0 & 100.0 & 100.0 & 66.7 & 100.0 & 100.0 & 100.0 & 66.7 & 66.7 & 66.7 \\
\hline Communications & 100.0 & 100.0 & 100.0 & 100.0 & 100.0 & 100.0 & 100.0 & 0.0 & 50.0 & 50.0 & 50.0 & 33.3 & 33.3 & 0.0 & 33.3 \\
\hline Construction & 93.3 & 90.0 & 91.8 & 90.9 & 88.9 & 100.0 & 71.4 & 33.3 & 60.0 & 60.0 & 71.4 & 57.1 & 50.0 & 60.0 & 60.0 \\
\hline Diversified Retailers & 40.0 & 66.7 & 50.0 & 60.0 & 100.0 & - & - & - & - & - & - & - & - & - & - \\
\hline Electricity & - & - & - & - & - & - & - & - & - & 0.0 & 100.0 & 100.0 & 100.0 & 100.0 & 100.0 \\
\hline Food and Beverages & 61.1 & 73.3 & 76.9 & 76.9 & 60.0 & 50.0 & 75.0 & 75.0 & 50.0 & 66.7 & 66.7 & 100.0 & 50.0 & 0.0 & 0.0 \\
\hline Informatic Systems & 40.0 & 80.0 & 60.0 & 66.7 & 33.3 & 100.0 & 100.0 & 100.0 & 100.0 & 100.0 & 100.0 & 100.0 & 100.0 & 100.0 & 0.0 \\
\hline Machines and Electrical Equipment & 80.0 & 60.0 & 66.7 & 100.0 & 100.0 & 100.0 & 100.0 & 50.0 & 50.0 & 100.0 & 100.0 & 50.0 & 0.0 & 0.0 & 0.0 \\
\hline Metallurgy & 80.0 & 80.0 & 50.0 & 42.9 & 33.3 & 33.3 & 33.3 & 50.0 & 100.0 & 100.0 & 100.0 & 100.0 & 100.0 & 100.0 & - \\
\hline Mineral non Metallic Industries & 77.8 & 71.4 & 71.4 & 71.4 & 100.0 & 60.0 & 50.0 & 66.7 & 83.3 & 66.7 & 80.0 & 80.0 & 80.0 & 33.3 & 33.3 \\
\hline Other Services Rendered to Firms & 53.8 & 81.8 & 81.8 & 72.7 & 88.9 & 88.9 & 66.7 & 66.7 & 77.8 & 54.5 & 54.5 & 77.8 & 70.0 & 50.0 & 20.0 \\
\hline Paper & 100.0 & 66.7 & 50.0 & 50.0 & 50.0 & 0.0 & 0.0 & 33.3 & 66.7 & 66.7 & 66.7 & 66.7 & 66.7 & 100.0 & 100.0 \\
\hline Real Estate & 100.0 & 100.0 & 50.0 & 66.7 & 50.0 & 50.0 & 50.0 & 50.0 & 50.0 & 50.0 & 50.0 & 100.0 & 100.0 & 100.0 & - \\
\hline Restaurants. Hotels and Leisure & 83.3 & 71.4 & 53.8 & 42.9 & 57.1 & 42.9 & 16.7 & 20.0 & 25.0 & 60.0 & 60.0 & 80.0 & 100.0 & 100.0 & 100.0 \\
\hline Textiles & 80.0 & 70.0 & 80.0 & 55.6 & 33.3 & 0.0 & 0.0 & - & - & - & - & - & - & - & - \\
\hline Tobacco & 100.0 & 0.0 & 100.0 & 0.0 & 100.0 & 100.0 & 100.0 & 100.0 & 100.0 & 0.0 & - & - & - & - & - \\
\hline Transport Activities & 45.5 & 50.0 & 40.0 & 40.0 & 50.0 & 20.0 & 0.0 & 0.0 & 0.0 & 0.0 & 50.0 & 50.0 & 50.0 & 66.7 & 66.7 \\
\hline Wholesale Trade & 60.0 & 80.0 & 40.0 & 33.3 & 50.0 & 0.0 & 0.0 & 0.0 & 0.0 & 0.0 & 0.0 & 50.0 & 50.0 & 0.0 & 0.0 \\
\hline
\end{tabular}


Table 3 - Dividend statistics by industry breakdown (continued)

\begin{tabular}{|c|c|c|c|c|c|c|c|c|c|c|c|}
\hline \multicolumn{12}{|c|}{ France } \\
\hline \multicolumn{12}{|c|}{ Panel A: Average DPS During 1992-2002 - Industry Breakdown, $€$} \\
\hline Industry & 1992 & 1993 & 1994 & 1995 & 1996 & 1997 & 1998 & 1999 & 2000 & 2001 & 2002 \\
\hline Aerospace, Airlines and Airports & 0.24 & 1.05 & 0.36 & 0.36 & 0.46 & 0.53 & 1.64 & 1.83 & 2.68 & 3.29 & 2.08 \\
\hline Agriculture & 0.76 & 0.76 & 0.76 & 0.76 & 2.77 & 1.83 & 1.45 & 1.60 & 2.44 & 3.05 & 1.64 \\
\hline Automobile & 0.41 & 0.45 & 0.46 & 0.41 & 0.57 & 0.58 & 0.61 & 0.73 & 0.86 & 1.28 & 1.02 \\
\hline Chemicals & 2.40 & 2.42 & 2.63 & 2.30 & 2.12 & 2.07 & 2.33 & 2.02 & 2.18 & 2.23 & 2.70 \\
\hline Communications & 0.33 & 0.37 & 0.39 & 0.39 & 0.35 & 0.41 & 0.62 & 0.66 & 0.79 & 1.14 & 0.52 \\
\hline Construction & 2.13 & 2.32 & 2.08 & 2.03 & 1.88 & 2.00 & 1.96 & 1.97 & 2.45 & 2.43 & 2.20 \\
\hline Diversified Industry & 0.99 & 0.76 & 0.76 & 0.76 & 0.76 & 1.52 & 1.83 & 2.00 & 2.50 & 1.62 & 1.93 \\
\hline Diversified Retailers & 0.52 & 0.62 & 0.70 & 0.74 & 0.78 & 0.80 & 1.03 & 1.11 & 1.19 & 1.11 & 1.30 \\
\hline Diversified Services & 1.04 & 1.28 & 1.07 & 1.52 & 0.79 & 0.92 & 1.26 & 1.37 & 1.53 & 5.50 & 3.50 \\
\hline Food and Beverages & 1.63 & 1.75 & 1.71 & 1.80 & 1.33 & 3.06 & 2.86 & 3.23 & 3.11 & 3.32 & 4.38 \\
\hline Informatic Systems & 0.60 & 0.41 & 0.47 & 0.63 & 0.54 & 0.66 & 0.62 & 0.47 & 0.62 & 0.52 & 0.61 \\
\hline Machines and Electrical Equipment & 0.38 & 0.38 & 0.26 & 0.31 & 0.50 & 0.56 & 0.84 & 0.80 & 0.71 & 0.66 & 0.58 \\
\hline Media and Publicity & 0.10 & 0.15 & 0.16 & 0.71 & 0.65 & 0.64 & 0.69 & 0.81 & 0.85 & 0.92 & 1.04 \\
\hline Metallurgy & 0.69 & 0.69 & 0.69 & 1.14 & 1.19 & 1.19 & 0.90 & 0.86 & 0.86 & 0.86 & 1.49 \\
\hline Mineral non Metallic Products & 0.95 & 0.97 & 0.97 & 1.00 & 0.92 & 1.16 & 1.05 & 1.07 & 1.25 & 1.65 & 1.36 \\
\hline Other Services Rendered to Firms & 1.17 & 0.98 & 0.72 & 0.74 & 1.16 & 1.12 & 1.04 & 0.90 & 0.98 & 1.18 & 1.41 \\
\hline Paper & 0.27 & 0.27 & 0.27 & 0.27 & 1.66 & 2.16 & 1.60 & 1.62 & 1.26 & 1.85 & 1.74 \\
\hline Real Estate & 3.44 & 5.49 & 5.48 & 2.65 & 2.70 & 2.64 & 2.31 & 2.87 & 2.33 & 1.99 & 2.72 \\
\hline Restaurants. Hotels and Leisure & 1.10 & 1.42 & 1.62 & 1.30 & 0.69 & 0.59 & 0.76 & 0.89 & 1.12 & 1.29 & 1.33 \\
\hline Textiles & 0.77 & 0.70 & 0.76 & 0.81 & 0.72 & 1.31 & 1.32 & 1.43 & 1.44 & 1.47 & 1.59 \\
\hline Tobacco & - & - & - & - & - & - & - & - & 0.48 & 0.55 & 0.55 \\
\hline Transport Activities & 0.88 & 1.09 & 1.09 & 1.09 & 1.14 & 1.54 & 0.96 & 1.13 & 1.17 & 1.40 & 2.05 \\
\hline Wholesale Trade & 0.44 & 0.48 & 0.47 & 0.49 & 0.57 & 0.62 & 0.71 & 0.78 & 0.85 & 0.93 & 0.91 \\
\hline \multicolumn{12}{|c|}{ Panel B: Percentage of Dividend Payers by Industry Breakdown } \\
\hline Industry & 1992 & 1993 & 1994 & 1995 & 1996 & 1997 & 1998 & 1999 & 2000 & 2001 & 2002 \\
\hline Aerospace, Airlines and Airports & 50.0 & 60.0 & 50.0 & 50.0 & 50.0 & 50.0 & 50.0 & 33.3 & 50.0 & 66.7 & 100.0 \\
\hline Agriculture & 14.3 & 14.3 & 16.7 & 20.0 & 16.7 & 50.0 & 50.0 & 50.0 & 33.3 & 25.0 & 66.7 \\
\hline Automobile & 66.7 & 83.3 & 69.2 & 83.3 & 90.9 & 90.9 & 81.8 & 81.8 & 91.7 & 91.7 & 83.3 \\
\hline Chemicals & 50.0 & 52.9 & 42.1 & 55.6 & 58.8 & 58.8 & 70.6 & 87.5 & 75.0 & 85.7 & 85.7 \\
\hline Communications & 50.0 & 33.3 & 40.0 & 40.0 & 40.0 & 50.0 & 60.0 & 60.0 & 50.0 & 50.0 & 37.5 \\
\hline Construction & 59.1 & 56.5 & 63.6 & 71.4 & 78.9 & 78.9 & 75.0 & 93.8 & 72.2 & 77.8 & 93.8 \\
\hline Diversified Industry & 5.0 & 5.9 & 5.9 & 6.7 & 8.3 & 8.3 & 11.1 & 14.3 & 20.0 & 40.0 & 50.0 \\
\hline Diversified Retailers & 15.4 & 19.0 & 23.5 & 25.0 & 27.8 & 31.3 & 33.3 & 45.5 & 55.6 & 85.7 & 85.7 \\
\hline Diversified Services & 1.7 & 4.0 & 4.5 & 2.6 & 6.1 & 6.9 & 7.7 & 9.1 & 11.1 & 20.0 & 33.3 \\
\hline Food and Beverages & 38.5 & 41.7 & 45.7 & 46.2 & 48.6 & 54.5 & 53.3 & 53.3 & 54.8 & 57.1 & 56.5 \\
\hline Informatic Systems & 18.2 & 22.2 & 30.0 & 30.0 & 36.4 & 41.7 & 54.5 & 60.0 & 56.3 & 50.0 & 52.9 \\
\hline Machines and Electrical Equipment & 13.6 & 17.6 & 16.7 & 16.7 & 18.8 & 18.8 & 21.4 & 25.0 & 33.3 & 45.5 & 63.6 \\
\hline Media and Publicity & 23.1 & 30.8 & 33.3 & 35.7 & 50.0 & 66.7 & 60.0 & 66.7 & 54.5 & 62.5 & 62.5 \\
\hline Metallurgy & 8.3 & 9.1 & 8.3 & 13.3 & 20.0 & 25.0 & 28.6 & 28.6 & 33.3 & 50.0 & 50.0 \\
\hline Mineral non Metallic Products & 35.3 & 37.5 & 37.5 & 42.9 & 42.9 & 54.5 & 66.7 & 75.0 & 75.0 & 75.0 & 50.0 \\
\hline Other Services Rendered to Firms & 37.5 & 50.0 & 40.0 & 44.4 & 55.6 & 62.5 & 83.3 & 85.7 & 75.0 & 54.5 & 54.5 \\
\hline Paper & 12.5 & 12.5 & 14.3 & 16.7 & 40.0 & 50.0 & 66.7 & 66.7 & 66.7 & 100.0 & 100.0 \\
\hline Real Estate & 34.5 & 36.5 & 39.6 & 42.2 & 48.7 & 47.5 & 58.8 & 63.6 & 64.5 & 75.0 & 75.0 \\
\hline Restaurants. Hotels and Leisure & 36.4 & 55.0 & 42.9 & 52.4 & 55.0 & 52.6 & 57.1 & 61.9 & 57.1 & 70.0 & 78.9 \\
\hline Textiles & 40.0 & 45.5 & 41.7 & 50.0 & 50.0 & 66.7 & 66.7 & 66.7 & 50.0 & 50.0 & 71.4 \\
\hline Tobacco & - & - & - & 0.0 & 0.0 & 0.0 & 0.0 & 0.0 & 50.0 & 50.0 & 50.0 \\
\hline Transport Activities & 11.8 & 12.5 & 13.3 & 13.3 & 14.3 & 23.1 & 41.7 & 55.6 & 50.0 & 71.4 & 71.4 \\
\hline Wholesale Trade & 37.5 & 42.9 & 42.9 & 42.9 & 42.9 & 42.9 & 42.9 & 50.0 & 50.0 & 50.0 & 62.5 \\
\hline
\end{tabular}

(Continue) 
Table 3 - Dividend statistics by industry breakdown (continued)

\begin{tabular}{|c|c|c|c|c|c|c|c|c|c|}
\hline \multicolumn{10}{|c|}{ UK } \\
\hline \multicolumn{10}{|c|}{ Panel A: Average DPS During 1994-2002 - Industry Breakdown, £ } \\
\hline Industry & 1994 & 1995 & 1996 & 1997 & 1998 & 1999 & 2000 & 2001 & 2002 \\
\hline Aerospace, Airlines and Airports & 5.82 & 5.91 & 5.96 & 6.82 & 7.61 & 8.43 & 9.15 & 10.17 & 10.19 \\
\hline Agriculture & 7.41 & 7.75 & 8.46 & 9.94 & 10.96 & 11.67 & 11.78 & 15.81 & 19.00 \\
\hline Automobile & 9.95 & 9.66 & 10.50 & 8.99 & 8.93 & 9.46 & 9.88 & 10.90 & 10.07 \\
\hline Chemicals & 9.31 & 9.83 & 9.18 & 10.02 & 10.09 & 9.93 & 10.97 & 12.03 & 12.60 \\
\hline Communications & 4.12 & 3.26 & 3.95 & 4.18 & 3.91 & 4.16 & 4.29 & 4.28 & 3.35 \\
\hline Construction & 5.32 & 5.68 & 6.04 & 6.63 & 6.87 & 7.22 & 7.85 & 8.15 & 8.69 \\
\hline Diversified Industry & 5.00 & 4.93 & 5.72 & 6.48 & 7.08 & 6.37 & 7.00 & 9.33 & 9.00 \\
\hline Diversified Retailers & 6.43 & 6.53 & 8.38 & 12.15 & 12.98 & 12.48 & 12.46 & 10.70 & 11.29 \\
\hline Diversified Services & 6.22 & 6.47 & 7.43 & 7.95 & 8.27 & 8.59 & 9.17 & 8.98 & 9.10 \\
\hline Electricity & 16.51 & 17.66 & 18.84 & 21.68 & 23.82 & 25.31 & 30.50 & 31.32 & 35.73 \\
\hline Food and Beverages & 8.12 & 8.46 & 8.97 & 9.10 & 9.61 & 10.69 & 11.87 & 11.94 & 13.02 \\
\hline Informatic Systems & 3.30 & 3.08 & 3.07 & 3.29 & 3.46 & 5.43 & 5.63 & 5.93 & 5.95 \\
\hline Machines and Electrical Equipment & 4.17 & 4.04 & 4.36 & 4.73 & 4.95 & 5.34 & 6.17 & 6.75 & 7.10 \\
\hline Media and Publicity & 6.47 & 7.07 & 7.33 & 7.26 & 7.31 & 7.11 & 7.35 & 7.13 & 7.18 \\
\hline Metallurgy & - & - & - & - & - & 5.44 & 7.73 & 5.56 & 9.12 \\
\hline Mineral non Metallic Products & 4.88 & 5.58 & 5.56 & 5.94 & 6.72 & 8.32 & 9.53 & 9.44 & 10.64 \\
\hline Other Services Rendered to Firms & 6.16 & 6.22 & 6.26 & 6.48 & 6.46 & 6.74 & 7.32 & 8.08 & 8.17 \\
\hline Paper & 3.94 & 4.61 & 5.04 & 5.62 & 6.18 & 6.33 & 6.78 & 7.16 & 7.26 \\
\hline Real Estate & 6.48 & 6.50 & 6.83 & 7.24 & 7.67 & 8.71 & 10.09 & 10.51 & 11.99 \\
\hline Restaurants. Hotels and Leisure & 4.67 & 4.71 & 5.32 & 5.64 & 5.75 & 6.40 & 6.55 & 7.28 & 7.45 \\
\hline Textiles & 6.37 & 5.28 & 7.46 & 7.66 & 7.95 & 7.94 & 7.63 & 9.65 & 8.49 \\
\hline Tobacco & 11.23 & 12.11 & 13.25 & 15.58 & 17.44 & 16.91 & 22.73 & 25.33 & 27.58 \\
\hline Transport Activities & 7.01 & 7.26 & 7.44 & 7.78 & 8.76 & 7.84 & 9.33 & 10.52 & 12.25 \\
\hline Wholesale Trade & 5.99 & 6.81 & 8.22 & 8.06 & 9.38 & 10.64 & 9.93 & 10.15 & 10.14 \\
\hline \multicolumn{10}{|c|}{ Panel B: Percentage of Dividend Payers by Industry Breakdown } \\
\hline Industry & 1994 & 1995 & 1996 & 1997 & 1998 & 1999 & 2000 & 2001 & 2002 \\
\hline Aerospace, Airlines and Airports & 66.7 & 68.8 & 75.0 & 80.0 & 70.6 & 70.6 & 70.6 & 70.6 & 64.7 \\
\hline Agriculture & 57.1 & 57.1 & 53.3 & 44.4 & 43.8 & 35.3 & 37.5 & 37.5 & 35.3 \\
\hline Automobile & 55.6 & 42.3 & 40.7 & 44.4 & 41.4 & 50.0 & 54.5 & 52.4 & 52.4 \\
\hline Chemicals & 30.5 & 32.4 & 35.1 & 33.8 & 33.7 & 35.8 & 35.4 & 36.5 & 37.0 \\
\hline Communications & 54.5 & 66.7 & 61.5 & 61.5 & 57.1 & 40.0 & 33.3 & 34.5 & 29.6 \\
\hline Construction & 56.8 & 57.0 & 58.0 & 57.8 & 60.2 & 65.8 & 69.7 & 79.7 & 79.7 \\
\hline Diversified Industry & 22.2 & 37.5 & 42.9 & 50.0 & 33.3 & 44.4 & 50.0 & 50.0 & 50.0 \\
\hline Diversified Retailers & 39.1 & 41.7 & 41.7 & 36.4 & 36.2 & 46.3 & 50.0 & 49.0 & 50.0 \\
\hline Diversified Services & 58.5 & 57.1 & 52.6 & 56.8 & 56.5 & 58.1 & 52.7 & 51.6 & 51.0 \\
\hline Electricity & 33.3 & 44.4 & 44.4 & 50.0 & 62.5 & 55.6 & 55.6 & 55.6 & 62.5 \\
\hline Food and Beverages & 49.2 & 49.2 & 50.0 & 55.7 & 52.2 & 53.7 & 55.6 & 60.0 & 58.3 \\
\hline Informatic Systems & 39.3 & 41.5 & 37.3 & 32.1 & 33.9 & 33.8 & 25.0 & 24.8 & 28.7 \\
\hline Machines and Electrical Equipment & 46.3 & 48.3 & 49.2 & 53.1 & 59.0 & 67.3 & 63.6 & 64.2 & 65.4 \\
\hline Media and Publicity & 44.4 & 38.1 & 39.6 & 41.2 & 42.9 & 50.9 & 52.7 & 57.4 & 56.6 \\
\hline Metallurgy & 0.0 & 0.0 & 0.0 & 0.0 & 0.0 & 28.6 & 33.3 & 40.0 & 25.0 \\
\hline Mineral non Metallic Products & 31.8 & 29.2 & 30.4 & 33.3 & 33.3 & 36.8 & 41.7 & 60.0 & 60.0 \\
\hline Other Services Rendered to Firms & 64.7 & 63.6 & 66.1 & 66.2 & 68.1 & 73.6 & 73.5 & 70.4 & 67.6 \\
\hline Paper & 33.3 & 33.3 & 33.3 & 33.3 & 33.3 & 50.0 & 100.0 & 100.0 & 100.0 \\
\hline Real Estate & 49.0 & 48.3 & 46.0 & 45.5 & 45.8 & 49.3 & 50.7 & 54.1 & 60.3 \\
\hline Restaurants. Hotels and Leisure & 44.4 & 48.8 & 53.3 & 48.1 & 55.8 & 54.5 & 54.5 & 53.8 & 51.9 \\
\hline Textiles & 29.6 & 33.3 & 38.5 & 40.0 & 43.5 & 47.6 & 42.1 & 41.2 & 41.2 \\
\hline Tobacco & 100.0 & 100.0 & 50.0 & 66.7 & 100.0 & 100.0 & 100.0 & 100.0 & 100.0 \\
\hline Transport Activities & 42.9 & 42.3 & 46.4 & 43.8 & 48.6 & 59.4 & 65.5 & 65.5 & 67.9 \\
\hline Wholesale Trade & 71.4 & 75.9 & 70.0 & 78.1 & 75.8 & 70.6 & 78.8 & 73.5 & 80.0 \\
\hline
\end{tabular}

